\title{
Alexandre Dumas, Gaule et France
}

\section{Lise Sabourin}

\section{OpenEdition}

\section{Journals}

\section{Édition électronique}

URL : http://journals.openedition.org/studifrancesi/10003

DOI : 10.4000/studifrancesi. 10003

ISSN : 2427-5856

\section{Éditeur}

Rosenberg \& Sellier

\section{Édition imprimée}

Date de publication : 1 août 2017

Pagination : 377

ISSN : 0039-2944

\section{Référence électronique}

Lise Sabourin, «Alexandre Dumas, Gaule et France », Studi Francesi [En ligne], 182 (LXI | II) | 2017, mis

en ligne le 01 août 2017, consulté le 06 janvier 2021. URL : http://journals.openedition.org/

studifrancesi/10003; DOI : https://doi.org/10.4000/studifrancesi.10003

Ce document a été généré automatiquement le 6 janvier 2021.

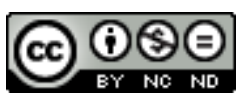

Studi Francesi è distribuita con Licenza Creative Commons Attribuzione - Non commerciale - Non opere derivate 4.0 Internazionale. 


\title{
Alexandre Dumas, Gaule et France
}

\author{
Lise Sabourin
}

\section{RÉFÉRENCE}

ALEXANDRE DUMAS, Gaule et France, édition critique par Julie Anselmini, Paris, Classiques

Garnier, 2015, 336 pp.

1 Ce livre, Gaule et France, paru chez Canel en 1833, correspond à un tournant chez Dumas père: célèbre par ses drames, il cherche une nouvelle voie dans la scrutation de ce Moyen-Âge que les romantiques sentent en parenté spirituelle avec leur mentalité. La mort de Scott en 1832, avec son art dramatique d'écrire l'histoire, exacerbe leur goût des chevaliers, des troubadours, des cathédrales gothiques, leur appétit de reconstituer ce passé où «il faut chercher le secret de l'avenir». Dumas qui a aussi participé activement aux journées de juillet 1830 se met donc en quête des sources de cette nation qu'il espère voir s'unir dans un progrès collectif. Aussi se plonge-t-il dans maintes sources érudites pour «apprendre l'histoire au peuple» par un écrit qui veut embrasser ses origines, depuis l'installation des Germains en Gaule jusqu'à la mort de Charles le bel au sein des divisions entre France et Angleterre.

2 Après une «introduction aux scènes historiques» (pp. 51-59) si à la mode dans ce début de la monarchie de Juillet, le «prologue» (pp. 61-67), bref mais immense par sa plongée dans le monde biblique et gréco-romain, remonte au peuplement initial de la Gaule. Dumas divise ensuite son propos en trois époques: le temps de la Gaule «Race conquérante» par une «Monarchie franco-romaine» (pp. 69-98), puis «Race conquérante» sous une «Monarchie franke», celle de Pépin le bref (pp. 99-138), enfin le surgissement de la France, par la «Monarchie française», avec Hugues Capet (pp. 139-227). Un «épilogue» (pp. 229-248) vient expliciter la conviction de l'écrivain: l'affranchissement des communes au XII ${ }^{\mathrm{e}}$ siècle, les mutations individuelles du XVIII ${ }^{\mathrm{e}}$ ont préparé l'émancipation du Tiers État et la division de la propriété effectuée par la Révolution, qui signent l'accès de tous à la liberté d'entreprendre menant à la république future. 
3 Julie Anselmini, qui édite ce texte en l'assortissant d'une notice biographique et d'un dossier (comportant les graphies anciennes adoptées pour les noms propres, d'utiles repères chronologiques, un descriptif des sources dont s'est servi Dumas et les comptes rendus du livre par la «Revue européenne», la «Revue de Paris» et le «Journal des débats», pp. 273-314), outre bibliographie et index nominum, précise bien dans son avant-propos (pp. 7-36) le statut de cet écrit dans le devenir dumasien. Épuisé d'avoir dû tant «apprend[dre] pour apprendre» à autrui (ce dont témoignent les notes de l'auteur, reportées en fin de texte, mais aussi les fragments insérés des historiens et chroniqueurs compilés), Dumas exploitera autrement ce «filon d'or», en «abandonnant la concision chronologique pour le développement pittoresque» (p. 23). Fasciné par ce passé brutal et merveilleux, adonné à la piété comme aux passions, il va continuer à vouloir embrasser l'histoire de France dans un projet totalisant dont il ne prendra vraiment conscience qu'a posteriori en 1857. Ses romans lui permettent de s'éloigner de la sécheresse des faits, d'ajouter des personnages inventés à côté des historiques, donc d'instruire en divertissant, qu'il s'agisse de La Reine Margot ou des Quarante-Cinq, des Trois Mousquetaires et ses suites ou du grand cycle révolutionnaire de Joseph Balsamo à La Comtesse de Charny. 